NBER WORKING PAPER SERIES

\title{
BIG-BOX RETAILERS AND URBAN CARBON EMISSIONS: THE CASE OF WAL-MART
}

\author{
Matthew E. Kahn \\ Nils Kok \\ Working Paper 19912 \\ http://www.nber.org/papers/w19912 \\ NATIONAL BUREAU OF ECONOMIC RESEARCH \\ 1050 Massachusetts Avenue \\ Cambridge, MA 02138 \\ February 2014
}

Kahn thanks the UCLA Ziman Center for Real Estate for generous funding. Kok is supported by a VENI grant from the Dutch Science Foundation (NWO). We thank Owen Hearey for valuable research assistance. We are grateful to Wal-Mart's Don Moseley for help in assembling, interpreting, and verifying the data used in this analysis. Wal-Mart did not provide any financial contribution to this research. Any errors are the responsibility of the authors. The views expressed herein are those of the authors and do not necessarily reflect the views of the National Bureau of Economic Research.

NBER working papers are circulated for discussion and comment purposes. They have not been peerreviewed or been subject to the review by the NBER Board of Directors that accompanies official NBER publications.

(C) 2014 by Matthew E. Kahn and Nils Kok. All rights reserved. Short sections of text, not to exceed two paragraphs, may be quoted without explicit permission provided that full credit, including $\odot$ notice, is given to the source. 
Big-Box Retailers and Urban Carbon Emissions: The Case of Wal-Mart

Matthew E. Kahn and Nils Kok

NBER Working Paper No. 19912

February 2014

JEL No. Q41,Q54

\begin{abstract}
$\underline{\text { ABSTRACT }}$
The commercial real estate sector is responsible for a large share of a city's overall carbon footprint. An ongoing trend in this sector has been the entry of big-box stores such as Wal-Mart. Using a unique monthly panel data set for every Wal-Mart store in California from 2006 through 2011, we document three main findings about the environmental performance of big-box retailers. First, Wal-Mart's stores exhibit very little store-to-store variation in electricity consumption relative to a control group of similar size and vintage retail stores. Second, Wal-Mart's store's electricity consumption is lower in higher priced utilities and is independent of the store's ownership versus leased status. Third, unlike other commercial businesses, Wal-Mart's newer buildings consume less electricity. Together, these results highlight the key roles that corporate size and centralization of management play in determining a key indicator of a firm's overall environmental performance.
\end{abstract}

Matthew E. Kahn

UCLA Institute of the Environment

Department of Economics

Department of Public Policy

Anderson School of Management

UCLA Law School, Box 951496

Los Angeles, CA 90095-1496

and NBER

mkahn@ioe.ucla.edu

Nils Kok

Department of Finance

Maastricht University, Room B1.08

P.O. Box 616

6200 MD Maastricht

The Netherlands

N.Kok@maastrichtuniversity.nl 


\section{Introduction}

Big-box retail stores represent a growing share of commercial real estate's total square footage in the United States, with Wal-Mart alone operating 641 million square feet of retail real estate in 2013. An ongoing policy debate has focused on how local quality of life, local public finances and local workers' total compensation are affected when "Wal-Mart comes to town." While the conventional wisdom is that big box retail stores cause the closings of competitor local retailers, recent academic research paints a more nuanced picture (see Emek Basker, 2007, Emek Basker et. al., 2012, and Russell S. Sobel and Andrea M. Dean, 2008). Critics have also been concerned that Wal-Mart causes extra local traffic and hence diminishes local quality of life, but Devin G. Pope and Jaren C. Pope (2012) conduct a hedonic event study and conclude that home prices increase in a vicinity of new Wal-Mart store openings. This capitalization approach suggests that Wal-Mart's openings raise quality of life or at least represent a new valuable amenity in residential areas where the firm choses to locate.

The greenhouse gas emissions of big-box retailers represent another metric for judging the impact of big-box stores. Retailers such as Wal-Mart produce greenhouse gas emissions when they transport goods from factories (often located in China) to their distribution centers in the U.S., and then on to their stores. Big-box retailers also generate greenhouse gas emissions at their stores, through energy consumption from heating and cooling, refrigeration, and lighting. This direct impact of big-box retailers on energy consumption is an important component of the real estate capital stock's carbon footprint. In 2012, 46 percent of the nation's electricity was generated using coal and 20 percent 
using natural gas. This reliance on fossil fuels for electricity generation means that there is a significant greenhouse gas externality associated with electricity consumption. ${ }^{1}$

In the absence of carbon pricing, no retailer has an incentive to take costly actions to reduce its greenhouse gas emissions, ${ }^{2}$ but of course, the sources of these emissions diesel for trucks and electricity for heating, cooling and lighting of stores - directly affect a firm's profitability. Indeed, in the diffusion of its stores, Wal-Mart evaluates the distance between potential locations to its distribution centers to economize on transportation costs (Thomas J. Holmes, 2011).

This paper builds on the nascent "big box" literature by examining the environmental performance of Wal-Mart's stores, with a focus on their electricity consumption. Using a unique monthly panel data that includes electricity consumption for every Wal-Mart store in California from 2006 to 2011, we document three main results about the energy performance of Wal-Mart's stores. First, there is a remarkable degree of consistency in Wal-Mart store electricity consumption per square foot of real estate. Across more than 200 Wal-Mart stores, the monthly variation in electricity consumption per square foot of real estate is much smaller than the across variation for a control sample of retail stores.

Second, we reject the hypothesis that this low dispersion in consumption in Wal-Mart stores is caused by the firm custom building stores to achieve a "cookie cutter" performance. Using data on the electricity consumption of stores that Wal-Mart has leased versus built for itself, we find no difference in electricity consumption.

\footnotetext{
${ }^{1}$ See http://www.eia.gov/totalenergy/data/annual/showtext.cfm?t=ptb0201f.

${ }^{2}$ A recent report finds that some of the largest global companies, including Wal-Mart, have recently started to incorporate a price on carbon in their long-term financial planning to anticipate future regulation on carbon emissions. See https://www.cdp.net/CDPResults/companies-carbon-pricing-2013.pdf.
} 
Third, we document evidence that newly constructed Wal-Mart stores have significantly lower electricity consumption than older buildings - this contrast with results documented for commercial buildings in general, where higher quality, newer vintages of commercial buildings actually consume more electricity than older buildings (Matthew E. Kahn et al., 2013).

We propose two hypotheses that can explain these facts. The first explanation focuses on the role of managerial human capital and expertise in generating a consistent environmental performance across operations. If there is a fixed cost to acquiring expertise in energy efficiency, then firms who operate numerous commercial buildings will have a greater incentive to make this investment than retailers who own and operate just one retail store. The human capital argument is an optimistic, albeit unexpected message for environmentalists, because it suggests that industrial concentration can actually lead to higher levels of energy efficiency (Nicholas Bloom et al., 2011).

The second hypothesis relates to the ability of large corporation to make more optimal capital investment decisions as compared to small, "mom and pop" storeowners. Large retailers such as Wal-Mart are economic decision-makers, not hindered by capital or liquidity constraints. Such firms that are led by professional managers, monitored by a board of directors, are less likely to suffer from behavioral biases that may otherwise lead to suboptimal investment in energy efficiency (Tom Tietenberg, 2009). It has been documented that across the retail sector, stores belonging to large chains tend to invest more in information technology (Lucia Foster et al., 2006). Indeed, Wal-Mart has been at the forefront in the adoption of tools for more efficient "production" (Thomas J. Holmes, 2011) and a similar effect seems to play out for optimizing building energy efficiency. 
We also document differences in energy efficiency based on local utility rates, which provides some support for this "rational optimization" hypothesis.

This paper's findings contribute to the empirical literature measuring corporate social responsibility (“CSR”). The CSR literature highlights the multitude of different rankings and criteria used for creating a single index of this ambiguous concept (see Antonio Márquez and Charles J. Fombrun, 2005, and Duygu Turker, 2009). To collapse a set of criteria into a single index requires index weights. These weights implicitly embed the sustainability priorities of the person creating the ranking.

Given the paramount importance of the climate change mitigation challenge, we argue that benchmarking big-box stores with respect to their in-house carbon production is an important exercise. Our approach can be scaled up to compare companies over time and to make cross-company comparisons at a point in time.

This paper also contributes to the recent literature on measuring the urban carbon footprint. This literature has focused on the residential carbon footprint generated by transportation and residential electricity consumption and home heating consumption (Edward L. Glaeser and Matthew E. Kahn, 2010). But, the commercial building sector is a major part of the urban capital stock, and the carbon emissions from these buildings now actually surpass the impact of transportation and the residential sector in most developed economies (Matthew E. Kahn, Nils Kok and John M. Quigley, 2013).

The remainder of this paper is organized as follows. Section II discusses the main determinants of how big-box stores contribute to greenhouse gas production, and develops the hypotheses tested in the paper. Section III provides an overview of the unique panel of data on energy consumption in a large set of Wal-Mart stores. Section IV 
presents the results of the estimations, and Section $\mathrm{V}$ provides a conclusion and discussion.

\section{The Economics of Carbon Emissions of Big-Box Retailers}

The impact of big-box retailers on global carbon emissions stems from several steps in the supply chain, including initial shipments of factory goods to the distribution center, distribution of these goods to the final retail stores and the activity that takes place in the retail stores. Of course, the manufacturing of goods also leads to carbon emissions, but these are generally considered to be outside of the scope of the big-box retailer, which acts as a "middleman."

At the point of sale, there are two factors at play in determining the energy impact of the purchase: the efficiency of the store, and the energy used by consumers when making their trip to the store. Wal-Mart has an incentive to locate near population centers and this reduces driving. ${ }^{4}$ Within a local retail market where a Wal-Mart operates, consumers face a choice concerning what retail trips to make to various retailers or perhaps travelling further to a Wal-Mart and making many purchases during that single trip (Morton E. O'Kelly, 1983, A. Okoruwa et al., 1988). Recent work by Kristin Lovejoy et al. (2013) documents that when a big-box Target store opens, vehicle miles travelled decline. This suggests that shoppers are making fewer trips and engage in more "one stop" shopping when the big-box store opens.

\footnotetext{
${ }^{3}$ With the outsourcing of manufacturing to low-cost countries, the carbon externality of production has now shifted away from the actual location of consumption.

${ }^{4}$ Wal-Mart's low prices mean that consumers buy more products, which ultimately leads to higher carbon emissions (Christian Broda et al., 2009). This raises an opportunity cost question of the carbon content of an extra dollar of Wal-Mart sales relative to all alternative uses for that dollar, but in this paper, we focus on carbon emissions from retail stores only.
} 
Once goods are stocked and consumers are at the store, the commercial building's attributes play a key role in determining the carbon impact of the product. For example, retail giant $\mathrm{H} \& \mathrm{M}$ emits 50 percent of its total corporate carbon emissions through electricity consumption in stores (and corporate offices). ${ }^{5}$ The buildings that firms own, lease, and operate thus represent an important part of their environmental impact, which has become increasingly relevant to corporations. Depending on whether a store is owned or leased (and, in case of the latter, the lease structure), a retailer has control over the quality of equipment for heating, ventilating and cooling the facility, as well as the quality of appliances such as lighting and refrigeration units.

Presumably, an on-site manager can influence the use-intensity of the equipment, which depends on the performance of the store, as well the training ("human capital") of the manager or his engineer. Research based on a sample of 300 British manufacturing firms highlights a negative correlation between firm energy intensity and an index of the firm's management quality (Nicholas Bloom et al., 2011). One explanation for this correlation is that management quality is associated with improved productivity and an indicator of productivity is output per unit of energy. Since energy consumption leads to greenhouse gas production, holding the scale of production constant, firms with higher quality management produce less greenhouse gas emissions.

\section{A. Main Empirical Hypotheses}

Given that technological progress, in combination with economies of scale and scope, have made Wal-Mart a major contributor to the overall increase in productivity and efficiency in the retail sector (Emek Basker, 2007), we expect that the environmental

\footnotetext{
${ }^{5}$ See H\&M “Conscious Actions Sustainability Report 2012” (p.60).
} 
performance of Wal-Mart stores differs from its peers. In particular, we focus on the "standardization" of environmental performance across stores, driven by the rollout of highly similar equipment across stores, and consistent training of on-site engineers.

H1: Wal-Mart stores feature limited dispersion in environmental performance, relative to a comparable group of control stores.

H2: The ownership structure of Wal-Mart stores has no effect on the environmental performance of these stores.

While residential electricity consumption patterns have been well-studied (see for a discussion Dirk Brounen et al., 2012, and Koichiro Ito, 2014), we know very little about how commercial buildings, occupied by some of the major corporations, perform over time, or about the heterogeneity of the performance. However, there is some evidence that sophisticated commercial owners and tenants capitalize energy savings when leasing or purchasing office space (Piet M.A. Eichholtz et al., 2013). We posit that Wal-Mart's size, access to capital, and management expertise allows it to act as if it is a "ruthless cost minimizer" that we observe in the intermediate micro textbooks. Such a firm would stand in contrast to inefficient residential consumers who, for a variety of potential reasons leave money on the table, the so-called "energy efficiency paradox" (for a discussion of the residential literature, see Hunt Allcott and Alan Greenstone, 2012).

For Wal-Mart, stores and other facilities represent the largest fraction of the corporate carbon footprint, and electricity represents the second-highest operating expense. These 
expenses rise proportionately with local energy prices and this provides a strong incentive to economize on energy consumption.

H3: In areas where electricity prices are higher, we expect Wal-Mart to display higher temperature-adjusted levels of energy efficiency.

In 2005, Wal-Mart pledged a corporate commitment to develop a store prototype that would be 25-30 percent more energy efficient by 2009. The corporate target was to reduce carbon emissions from existing facilities by 20 percent in 2011 (compared to 2005).

While this suggests that Wal-Mart's new stores would be more energy efficient than older stores, Wal-Mart has also made investments to retrofit its older stores. Wal-Mart has embarked on an energy efficiency program, including lighting retrofits through replacing conventional lighting by LEDs, and installing more efficient refrigeration units. ${ }^{6}$ The empirical results reported below recover estimates of the net differential electricity consumption in recent vintage Wal-Mart stores as compared to earlier vintage Wal-Marts, allowing us to test whether the vintage effects documented by Matthew E. Kahn et al. (2013), where newer, higher quality buildings consumer more electricity than otherwise comparable, but older buildings, holds for big-box retailers.

H4: Newly constructed Wal-Mart stores outperform less recently constructed stores in energy-use intensity

\footnotetext{
6 See http://corporate.walmart.com/global-responsibility/environment-sustainability/buildings for more information.
} 


\section{Data and Methods}

Through a unique research partnership with Wal-Mart, we obtain access to information on the monthly electricity consumption across all Wal-Mart stores in California. This information includes both consumption, as well as the physical characteristics of the stores, such as year of construction, size and store type (Sam's Club, Supercenter, or Wal-Mart). Of course, weather is an important determinant of electricity consumption in buildings. Using geocoding techniques, each Wal-Mart store is assigned to the reporting weather station closest to the centroid of the zip code containing the store, where the temperature data comes from NOAA's National Climatic Data Center. ${ }^{7}$ We also obtain information on the utility district corresponding with each of the stores (in our case, we focus on San Diego Gas \& Electric, Southern California Edison, and Pacific Gas \& Electric), and the wholesale electricity prices in the districts.

Figure 1 shows a map of the stores that we study in this paper. To put this into perspective: Wal-Mart currently operates 4,663 stores across all states in the U.S., including 3,182 Supercenters, 620 Sam's Clubs, and 554 "regular" Wal-Mart stores (as well as 258 Neighborhood Markets and a small number of other store concepts).

To make comparisons with the energy efficiency of retail stores that are not owned and/or operated by Wal-Mart, we create a matched sample of retail stores located in a "Western" utility district. An elaborate description of the dataset is in Matthew E. Kahn et al. (2013). To make more precise evaluations, we apply two additional selection criteria. First, we focus on stores that are comparable in size (between 50,000 and 250,000 sq.ft.). Second, we run a propensity score model, predicting the likelihood of a

\footnotetext{
${ }^{7}$ See http://www.ncdc.noaa.gov/cdo-web/.
} 
store in the control sample to be a Wal-Mart store by its observable characteristics, such as building size and age. We then match each Wal-Mart store with its "nearest neighbor" (see Dan A. Black and Jeffrey A. Smith, 2004, for an application), based on the estimated propensity scores.

To test the first hypothesis, which focuses on the "standardization" of Wal-Mart activity across stores, we estimate the variation in energy consumption per square foot (the "energy use intensity") for all Wal-Mart stores, and for our set of control stores in the same geographic area:

(1) $\ln \left(E_{i t}\right)=\beta T E M P_{i t}+\varepsilon_{i t}$

In equation (1), we regress the natural logarithm of the energy use per square foot in Wal-Mart store $i$ in month $t$ on a spline of outdoor temperature knots and an error term (assumed i.i.d.). We then predict the average store electricity consumption holding outdoor temperature constant.

We also report results based on estimating equation (2), which represents a reducedform regression model explaining the energy use intensity per square foot as a function of outdoor temperature, building attributes and other observable characteristics:

(2) $\ln \left(E_{i t}\right)=\beta_{1} T E M P_{i t}+\beta_{2} T Y P E_{i}+\beta_{3} X_{i}+\tau_{m}+\gamma_{u}+\varepsilon_{i t}$

In equation (2), TYPE $E_{i}$ are store type-fixed effects (Supercenter, Wal-Mart, or Sam's Club), $X_{i}$ is a vector of store-specific characteristics, such as its vintage and size, $\tau_{\mathrm{m}}$ are month-fixed effects, controlling for unobservable shocks to electricity consumption common to each store $i$. To control more precisely for locational effects as related to local electricity rates, we include a set of dummy variables, $\gamma_{u}$, one for each unique electric utility. $\varepsilon_{\text {it }}$ is an error term, assumed to be i.i.d. 


\section{Results}

\section{A. Standardization of Wal-Mart Stores}

In this section, we study the hypothesis that Wal-Mart consistently applies the same energy management practices across its large set of stores. As our sample of Wal-Mart stores covers a wide area across California, the variation in climate and the intensity of business activities yields different requirements regarding temperature settings, lighting, and other energy-consuming equipment and appliances. Given that the varying locations feature different local labor markets, it is possible that worker discretion over day-to-day activities at the store (for example, heating or cooling settings) and design decisions over lighting, insulation, and cooling, could lead to very different energy consumption patterns across stores.

Figure 2 shows the energy consumption per square foot for the sample of Wal-Mart stores and the control sample. These simple comparisons provide some insight into the deviation from the average consumption in both samples. The estimations of Model (1) are reported in Table 1. This table reports the empirical distribution of the average electricity consumption by store while standardizing for outdoor temperature. The key finding is the minimal dispersion of energy consumption per square foot across all WalMart stores, and per store type. For Wal-Mart, its stores in the $99^{\text {th }}$ percentile (i.e., the least efficient stores) consume just 34 percent more energy as compared to the average Wal-Mart store, and stores in the $1^{\text {st }}$ percentile (i.e., the most efficient stores) consume only about 50 percent less as compared to the average Wal-Mart store. 
Columns (5) and (6) show the variation of energy consumption based on estimates of equation (1) for the control sample. For all retail buildings in the control sample, the least efficient stores $\left(99^{\text {th }}\right.$ percentile) consume almost three times as much electricity as compared to the average store. This variation is slightly smaller for the propensity-score matched sample.

These findings suggest that Wal-Mart standardizes the construction and operation of the energy performance of its stores. The absence of wide differentials across stores suggests that centralized management practices are more important than any idiosyncratic store-specific factors, such as the assignment of one building engineer to a store. In contrast, in our control sample, buildings are owned and operated by a large variety of investors and tenants. This leads to idiosyncratic factors more strongly influencing building energy consumption, where some buildings are operated in a highly efficient manner, and some other buildings running inefficiently. It is important to emphasize that our control group set of stores represents other retail stores of similar size and vintage.

\section{B. Capital Vintage Effects}

The environmental implications of the capital stock differ across sectors. In the case of electric utilities, many older power plants are grandfathered and do not face severe Clean Air Act regulations (Randy A. Nelson et al., 1993). In the case of cars, the vehicle fleet's local pollution emissions have been falling sharply over time as new vehicles emit much less pollution per mile than early model year vehicles such as those build in the 1970s (Matthew E. Kahn and Joel Schwartz, 2008). In the case of fleet fuel economy, 
Christopher R. Knittel (2012) documents that fuel economy progress slowed down during the times of low gas prices as new car makers focused on other dimensions of quality.

In contrast, in the case of commercial real estate, Matthew E. Kahn et al. (2013) document a positive correlation between commercial building quality and electricity consumption. They argue that for commercial real estate, the quality of real estate and electricity consumption are likely to be complements. This hypothesis suggests that, in the absence of carbon pricing, as the older lower quality commercial real estate stock is replaced with new, higher quality capital, that energy consumption per square foot will rise.

Table 2 shows the estimation results of equation (2), documenting that more recently constructed Wal-Mart stores consume significantly less electricity than older stores. ${ }^{8}$ Stores built during the past decade use about four percent less electricity as compared to stores constructed before 1995. This finding contrasts with findings for commercial real estate in general. Whereas quality and energy consumption are complements for most of the durable building stock, Wal-Mart keeps the quality of the stores constant, while improving the efficiency of the equipment, leading to a decrease in energy use intensity for newly constructed stores.

\section{Efficient Investments}

We also test hypotheses related to the role of commercial real estate ownership structure and local electric utility energy pricing in determining a Wal-Mart store's

\footnotetext{
${ }^{8}$ In studying the impact of these factors on big-box store electricity consumption, we use our unique data set. Despite the number of variables that we can access, we recognize that there will be unobserved determinants of building electricity consumption. In estimating equation (2) using OLS, we are assuming that the error term is not correlated with the explanatory variables.
} 
electricity consumption. For each Wal-Mart store, we know whether the commercial building is leased or is owned by Wal-Mart. If Wal-Mart engages in customization of buildings that creates energy efficiency, then we would expect to find that leasing has a positive effect on electricity consumption (i.e., it increases consumption, ceteris paribus). As shown in Column (2) of Table 2, we cannot reject the hypothesis that the coefficient is zero. This result suggests that central management takes actions to negate any initial conditions such that a leased piece of real estate is inherently inefficient. Since Wal-Mart is the tenant, it has no short run incentive to modify the structure of the building itself.

From the location of each Wal-Mart store, we also know the corresponding utility district. Presumably, a value-maximizing corporation would invest more in energy efficiency in areas where energy prices are higher. In Column (2) of Table 2, we report the coefficient estimates for the dummy variables for each of the major utilities (PG\&E is the base dummy). We find the largest negative coefficient for Wal-Mart stores in the San Diego (SDGE) territory. This is the utility where commercial consumers face the highest average prices ${ }^{9}$ and we find that Wal-Mart store electricity consumption is 9 percent lower as compared to electricity consumption in stores that are located in the cheaper PG\&E territory. It is important to note that these results include controls for local temperature conditions.

\section{Conclusions}

The commercial real estate sector is a major determinant of a city's overall carbon footprint. While all major companies discuss their efforts to achieve corporate socially

\footnotetext{
${ }^{9}$ See http://www.energy.ca.gov/2011_energypolicy/documents/2011-08-30_workshop/mid-case/
} 
responsibility targets, these quantitative measures are often elusive and do not often provide direct information about the firm's true environmental social costs.

In this paper, we argue that a company's electricity consumption is a verifiable and meaningful indicator of its overall environmental performance. We investigate the energy consumption differences for Wal-Mart stores in California as compared to similar retail stores of similar size and building age owned and/or managed by a diverse set of investors and tenants. We document strong evidence of standardization across buildings by Wal-Mart, leading to limited variation in energy consumption across buildings. The electricity consumption of Wal-Mart stores does not depend on the ownership status of the actual stores (leased versus owned), but stores that are located in more expensive utility areas feature lower electricity consumption. We also find that newer Wal-Mart stores consume less electricity as compared to older stores. This result stands in contrast to other findings for commercial buildings.

Together, these results highlight the role that both management and access to financial capital may play in determining the retail sector's environmental performance. Our findings suggest that large corporations are more likely to make investments in improving the efficiency of their durable capital. Given our data, we are unable to disentangle how much of this fact is due to better access to capital, a focus on cost minimization rather than "utility maximization," or access to better human capital in managing the firm's capital stock. All of these factors imply that industrial concentration can actually lead to higher levels of energy efficiency.

The results in this paper also provide a perspective on carbon emissions as an externality from activities in the commercial real estate sector, and how large 
corporations might be affected if carbon were to be priced. Some simple calculations show that, using the 2009 emission factor for California and an assumed social cost of carbon of $\$ 32$ per ton of carbon dioxide, the total carbon externality from Wal-Mart stores in California is $\$ 7$ million (in 2009), or 23 cents/sq.ft. ${ }^{10}$ This is a tangible corporate environmental performance measure that can be compared over time and across different commercial real estate entities, and across different corporate occupiers of commercial real estate such as big-box retailers.

\footnotetext{
${ }^{10}$ We use the U.S EPA Egrid data to estimate the average carbon emissions factor for California electric utilities (see http://www.epa.gov/cleanenergy/energy-resources/egrid/index.html).
} 


\section{References}

Allcott, Hunt. 2011. "Social Norms and Energy Conservation." Journal of Public Economics, 95(5), 1982-095.

Allcott, Hunt and Michael Greenstone. 2012. "Is There an Energy Efficiency Gap?" Journal of Economic Perspectives, 26(1), 3-28.

Basker, Emek. 2007. "The Causes and Consequences of Wal-Mart's Growth." Journal of Economic Perspectives, 21(3), 177-98.

Bloom, Nicholas; Christos Genakos; Ralf Martin and Raffaella Sadun. 2011. "Modern Management: Good for the Environment, or Just Hot Air?" Economic Journal, 120, 551-72.

Broda, Christian; Ephraim Leibtag and David E. Weinstein. 2009. "The Role of Prices in Measuring the Poor's Living Standards." Journal of Economic Perspectives, 23(2), 77-97.

Brounen, Dirk; Nils Kok and John M. Quigley. 2012. "Residential Energy Use and Conservation: Economics and Demographics." European Economic Review, 56(5), 93145.

Eichholtz, Piet M.A.; Nils Kok and John M. Quigley. 2013. "The Economics of Green Building." Review of Economics and Statistics, 95(1), 50-63.

Foster, Lucia; John Haltiwanger and C. J. Krizan. 2006. "Market Selection, Reallocation and Restructuring in the U.S. Retail Trade Sector in the 1990s." Review of Economics and Statistics, 88(4), 748-58.

Glaeser, Edward L. and Matthew E. Kahn. 2010. "The Greenness of Cities: Carbon Dioxide Emissions and Urban Development." Journal of Urban Economics, 67(3), 40418.

Holmes, Thomas J. 2011. "The Diffusion of Wal - Mart and Economies of Density." Econometrica, 79(1), 253-302.

Ito, Koichiro. 2014. "Do Consumers Respond to Marginal or Average Price? Evidence from Nonlinear Electricity Pricing." American Economic Review, 140(2), 537-63.

Kahn, Matthew E.; Nils Kok and John M. Quigley. 2013. "Commercial Building Electricity Consumption Dynamics: The Role of Structure Quality, Human Capital, and Contract Incentives," NBER Working Paper Series \#18781.

Kahn, Matthew E. and Joel Schwartz. 2008. "Urban Air Pollution Progress Despite Sprawl: The "Greening" of the Vehicle Fleet." Journal of Urban Economics, 63(3), 77587. 
Knittel, Christopher R. 2012. "Automobiles on Steriods: Product Attribute Trade-Offs and Technological Progress in the Automobile Sector." American Economic Review, 101(7), 3368-99.

Lovejoy, Kristin; Gian-Claudia Sciara; Deborah Salon; Susan Handy and Patricia Mokhtarian. 2013. "Measuring the Impacts of Local Land-Use Policies on Vehicle Miles of Travel: the Case of the First Big-Box Store in Davis, California." Journal of Transport and Land Use, 6(1), 25-39.

Márquez, Antonio, and Charles J. Fombrun. "Measuring corporate social responsibility." Corporate Reputation Review 7, no. 4 (2005): 304-308.

Nelson, Randy A.; Tom Tietenberg and Michael R. Donihue. 1993. "Differential Environmental Regulation: Effects on Electric Utility Capital Turnover and Emissions." Review of Economics and Statistics, 75(2), 368-73.

O'Kelly, Morton E. 1983. "Multipurpose Shopping Trips and the Size of Retail Facilities." Annals of the Association of American Geographers, 73(2), 231-39.

Okoruwa, A.; Joseph V. Terza and Hugh O. Nourse. 1988. "Estimating Patronization Shares for Urban Retail Centers: An Extension of the Poisson Gravity Model." Journal of Urban Economics, 24(3), 241-59.

Pope, Devin G. and Jaren C. Pope. 2012. "When Walmart Comes to Town: Always Low Housing Prices? Always?," NBER Working Paper Series \#18111.

Tietenberg, Tom. 2009. "Reflections-Energy Efficiency Policy: Pipe Dream or Pipeline to the Future?" Review of Environmental Economics and Policy, 3(2), 304-20.

Turker, Duygu. "Measuring corporate social responsibility: A scale development study." Journal of Business Ethics 85, no. 4 (2009): 411-427. 
Figure 1

The Geography of Wal-Mart Stores in California in 2012
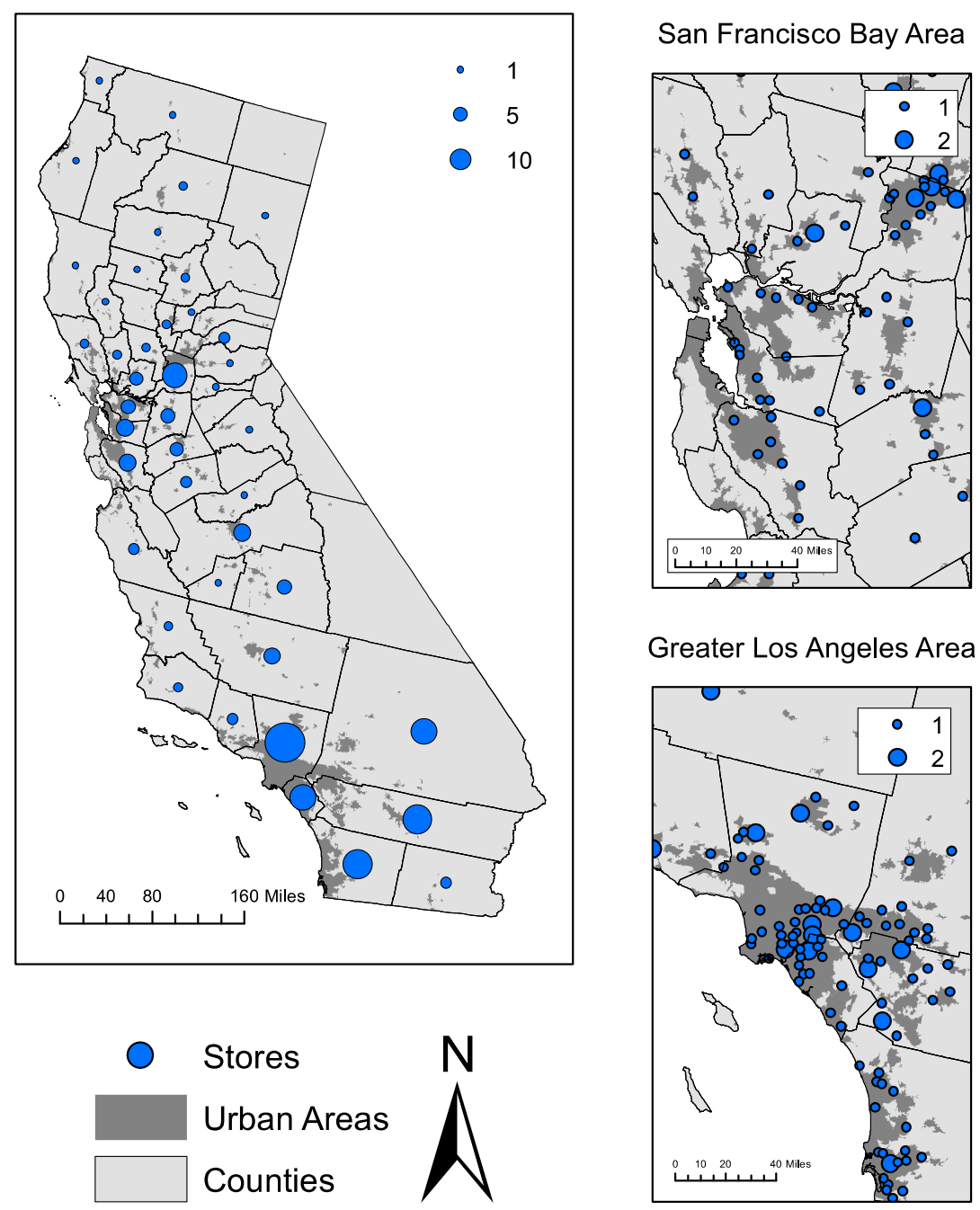

Greater Los Angeles Area

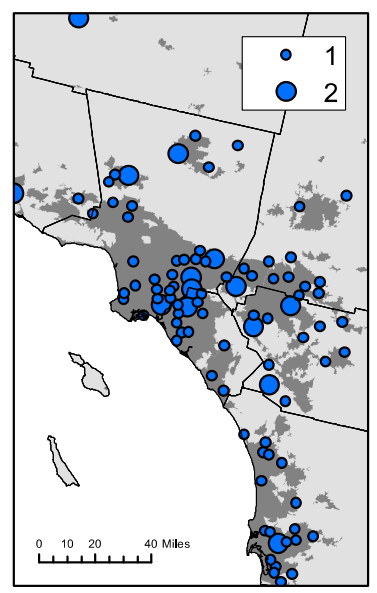


Figure 2

Monthly Energy Consumption for Wal-Mart Stores and the Control Sample (Winter and Summer, 2006-2010)

\section{A. Winter (January)}

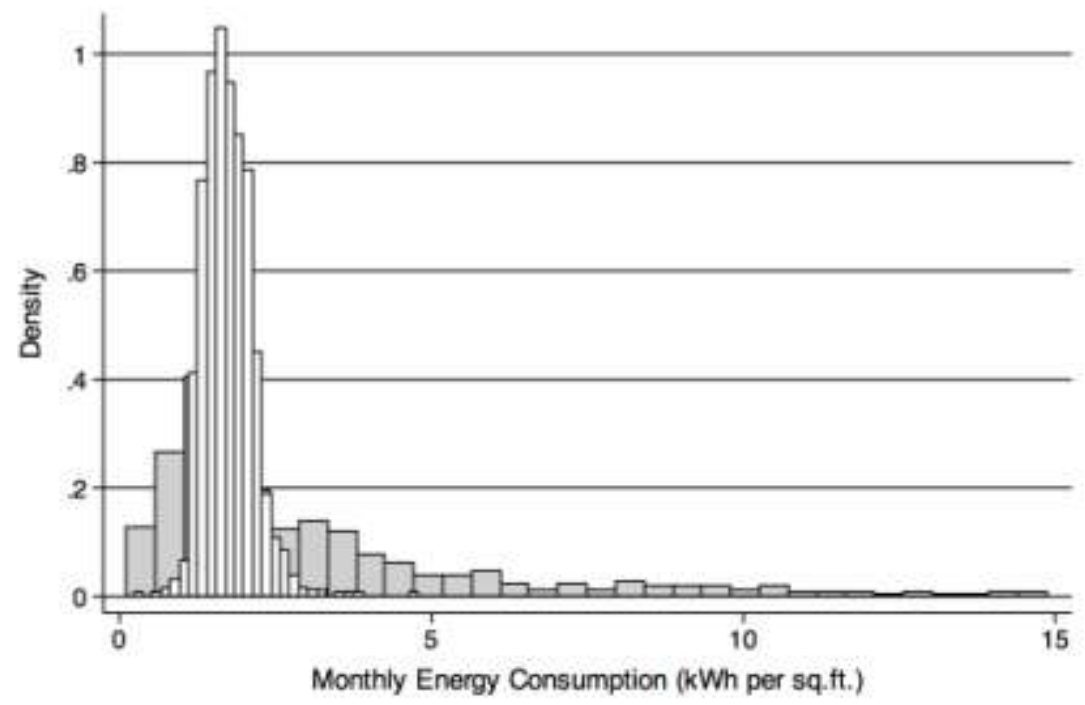

Notes: The distribution of the monthly electricity consumption in Wal-Mart stores in in white, and the distribution of the monthly electricity consumption in stores in the control sample is in grey.

\section{B. Summer (July)}

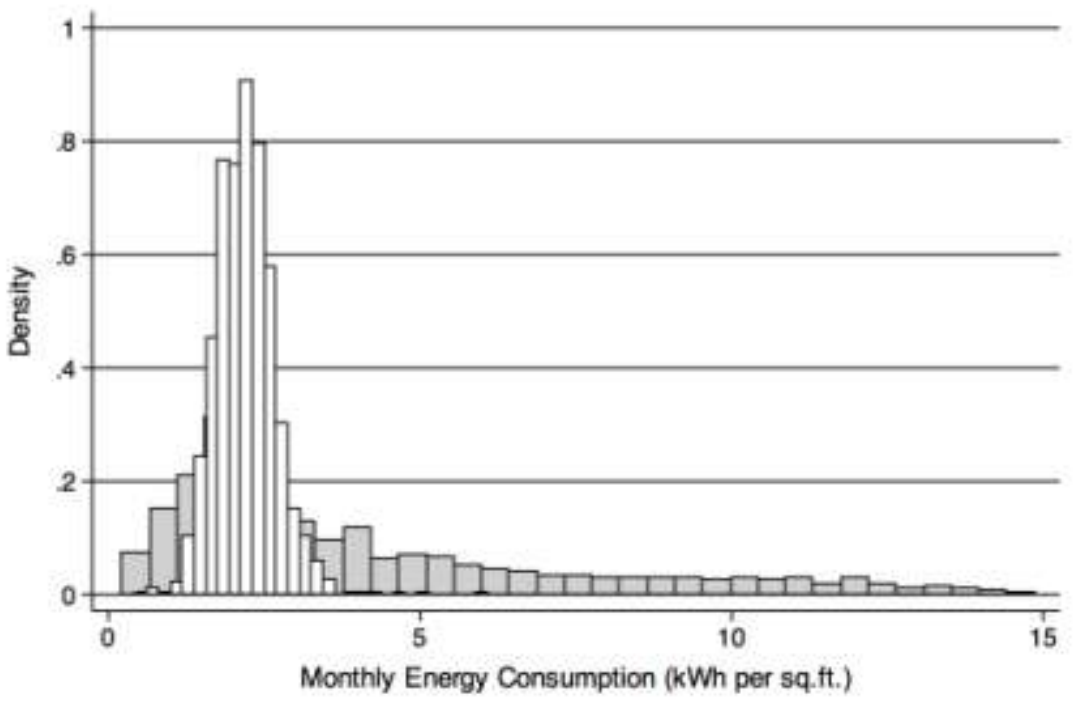

Notes: The distribution of the monthly electricity consumption in Wal-Mart stores in in white, and the distribution of the monthly electricity consumption in stores in the control sample is in grey. 
Table 1

Cross-Sectional Dispersion in Energy Consumption

Wal-Mart Stores and the Control Sample

\begin{tabular}{|c|c|c|c|c|c|c|}
\hline & (1) & (2) & (3) & (4) & (5) & (6) \\
\hline & \multicolumn{4}{|c|}{ Wal-Mart Sample } & \multicolumn{2}{|c|}{ Matched Sample } \\
\hline & All & Sam's Club & Supercenter & Wal-Mart & All Retail & PSM Sample \\
\hline \multicolumn{7}{|l|}{ Percentiles } \\
\hline $1 \%$ & -0.491 & -0.196 & -0.746 & -0.250 & -1.914 & -1.818 \\
\hline $5 \%$ & -0.244 & -0.184 & -0.279 & -0.176 & -1.163 & -1.403 \\
\hline $10 \%$ & -0.197 & -0.136 & -0.250 & -0.127 & -0.865 & -0.938 \\
\hline $25 \%$ & -0.105 & -0.070 & -0.097 & -0.087 & -0.443 & -0.399 \\
\hline $50 \%$ & -0.004 & -0.012 & 0.029 & 0.003 & 0.145 & -0.020 \\
\hline $75 \%$ & 0.119 & 0.065 & 0.117 & 0.070 & 0.909 & 0.601 \\
\hline $90 \%$ & 0.205 & 0.116 & 0.193 & 0.115 & 1.492 & 1.378 \\
\hline $95 \%$ & 0.283 & 0.154 & 0.273 & 0.206 & 1.978 & 1.688 \\
\hline $99 \%$ & 0.339 & 0.202 & 0.371 & 0.288 & 2.761 & 2.580 \\
\hline $\mathrm{N}$ & 219 & 34 & 88 & 97 & 385 & 133 \\
\hline
\end{tabular}

Notes:

The table reports the empirical distribution of the average electricity consumption by store while standardizing for outdoor temperature, based on estimating equation (1).

"All Retail" includes retail stores that are comparable in size (between 50,000 and 250,000 sq.ft.).

"PSM Sample" includes retail stores that are the "nearest neighbor" match for each Wal-Mart store, based on estimated propensity scores. 


\section{Table 2 \\ Determinants of Energy Consumption: Vintage, Price and Type (Wal-Mart Sample)}

\begin{tabular}{|c|c|c|}
\hline & $(1)$ & $(2)$ \\
\hline \multicolumn{3}{|l|}{ Temperature Splines } \\
\hline Temperature up to 65 degrees & $\begin{array}{l}0.005 * * * \\
(0.001)\end{array}$ & $\begin{array}{l}0.008 * * * \\
(0.001)\end{array}$ \\
\hline Temperature from 65 to 75 degrees & $\begin{array}{l}0.032 * * * \\
(0.001)\end{array}$ & $\begin{array}{l}0.031 * * * \\
(0.001)\end{array}$ \\
\hline Temperature over 75 degrees & $0.029 * * *$ & $0.029 * * *$ \\
\hline Vintage $(>15$ years $=$ base dummy $)$ & $(0.002)$ & $(0.002)$ \\
\hline Construction Period $(<10$ years $)$ & $\begin{array}{l}-0.040 * * * \\
(0.007)\end{array}$ & $\begin{array}{l}-0.035^{* * *} \\
(0.007)\end{array}$ \\
\hline Construction Period (10-15 years) & $\begin{array}{l}0.048 * * * \\
(0.009)\end{array}$ & $\begin{array}{l}0.060 * * * \\
(0.009)\end{array}$ \\
\hline \multicolumn{3}{|c|}{ Store Type (Sam's Club = base dummy) } \\
\hline Supercenter & $\begin{array}{l}-0.320 * * * \\
(0.009)\end{array}$ & $\begin{array}{l}-0.326 * * * \\
(0.009)\end{array}$ \\
\hline Wal-Mart & $\begin{array}{l}-0.522 * * * \\
(0.009)\end{array}$ & $\begin{array}{l}-0.521 * * * \\
(0.009)\end{array}$ \\
\hline Leased Store & & $\begin{array}{c}0.002 \\
(0.007)\end{array}$ \\
\hline $\begin{array}{l}\text { Utility (PG\&E = base dummy) } \\
\text { SDGE }\end{array}$ & & $\begin{array}{l}-0.096 * * * \\
(0.011)\end{array}$ \\
\hline SCE & & $\begin{array}{l}-0.044 * * * \\
(0.008)\end{array}$ \\
\hline Other & & $\begin{array}{l}0.091 * * * \\
(0.009)\end{array}$ \\
\hline Month-Fixed Effects & $\mathrm{Y}$ & $\mathrm{Y}$ \\
\hline Constant & $\begin{array}{l}1.925^{* * *} \\
(0.045)\end{array}$ & $\begin{array}{l}1.788 * * * \\
(0.046)\end{array}$ \\
\hline Number of Stores & 219 & 219 \\
\hline Observations & 15,847 & 15,847 \\
\hline $\mathrm{R}^{2}$ & 0.375 & 0.388 \\
\hline Adj. $R^{2}$ & 0.374 & 0.387 \\
\hline
\end{tabular}

Notes:

The table reports the estimation results of equation (2). The dependent variable is the natural logarithm of the energy use per square foot.

Standard errors in parentheses $* * * \mathrm{p}<0.01, * * \mathrm{p}<0.05, * \mathrm{p}<0.1$ 